\title{
Drugs for the Treatment of Chronic Hand Eczema: Successes and Key Challenges [Corrigendum]
}

\author{
Dubin C, Del Duca E, Guttman-Yassky E. Ther Clin Risk \\ Manag. 2020;16:1319-1332.
}

The authors have advised the drug, ARQ-252, was misnamed in the paper as roflumilast (which is called ARQ151 and ARQ-154 by the manufacturer). The drug named ARQ-252 by the manufacturer should instead be classified as a JAK1 inhibitor in the paper.

On page 1320, CHE Treatment Paradigm section, $1^{\text {st }}$ paragraph, "There are also ongoing studies with phosphodiesterase type 4 inhibitors (PDE4) and inhibitors of highly inflammatory chemokines CCL2 and CCL5 for the treat-

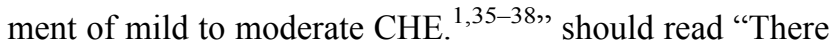
are also ongoing studies with topical JAK1 inhibitors and inhibitors of highly inflammatory chemokines CCL2 and CCL5 for the treatment of mild to moderate CHE. ${ }^{1,35-38, "}$

On page 1322, Table 1, Agent and Target/Mechanism columns, "Roflumilast (ARQ-252)" should read "ARQ252" and "PDE4" should read "JAK1".

On page 1323, before Roflumilast section, new section added for ARQ-252:

\section{ARQ-252}

Another topical JAK inhibitor is currently under investigation for the treatment of CHE. ARQ-252, a topical JAK1 inhibitor, is under clinical evaluation in a phase $1 / 2 b$ randomized parallel assignment trial involving 223 patients with chronic hand eczema. ${ }^{37,90}$

On page 1323, Roflumilast section now reads "Roflumilast is a high potency selective inhibitor of the receptor for PDE4, which functions by degrading cyclic adenosine monophosphate (cAMP) ${ }^{89}$ Blocking the PDE-4 receptor allows cAMP to signal the transcription of immune function genes such as anti-inflammatory IL-10, while simultaneously reducing the production of inflammatory cytokines such as TNF $\alpha$ and IFN $\gamma$, which have been identified as possibly involved in CHE. ${ }^{15,91-93}$ Roflumilast has been investigated as a topical therapeutic for $\mathrm{AD},{ }^{89}$ and though there are no current trials, it remains a possible therapeutic option for CHE in the future.

The authors apologize for this error.

\section{Publish your work in this journal}

Therapeutics and Clinical Risk Management is an international, peerreviewed journal of clinical therapeutics and risk management, focusing on concise rapid reporting of clinical studies in all therapeutic areas, outcomes, safety, and programs for the effective, safe, and sustained use of medicines. This journal is indexed on PubMed Central, CAS,
EMBase, Scopus and the Elsevier Bibliographic databases. The manuscript management system is completely online and includes a very quick and fair peer-review system, which is all easy to use. Visit http://www.dovepress.com/testimonials.php to read real quotes from published authors. 